\title{
Airway inflammation after removal from the causal agent in occupational asthma due to high and low molecular weight agents
}

\author{
L-P. Boulet*, M. Boutet*, M. Laviolette*, M. Dugas**, J. Milot*, C. Leblanc**, \\ L. Paquette**, J. Côté*, A. Cartier**, J-L. Malo**
}

Airway inflammation after removal from the causal agent in occupational asthma due to high and low molecular weight agents. L-P. Boulet, M. Boutet, M. Laviolette, M. Dugas, J. Milot, C. Leblanc, L. Paquette, J. Côté, A. Cartier, J-L. Malo. CERS Journals Ltd 1994.

ABSTRACT: In order to determine 1) the features of airway inflammation after removal from exposure to high (HMW) and low (LMW) molecular weight agents 2) if there are any differences in the pattern of inflammation induced by these two types of agents, we studied 18 subjects with a recently confirmed diagnosis of occupational asthma (OA) due to HMW (n=11) and LMW (n=7) agents.

The duration of asthma symptoms varied from 2 to 108 months (mean 33 months), and withdrawal from exposure to the sensitizing agent from 3 to 24 weeks (mean 10 weeks). All subjects underwent measurements of expiratory flow rates, methacholine inhalation tests, and a flexible bronchoscopy with bronchoalveolar lavage (BAL) and bronchial biopsies. Endoscopic findings were compared with a group of 10 normal subjects. At the time of the bronchoscopy, asthma symptoms were minimal in most subjects.

Although 15/18 subjects had normal forced expiratory volume in one second $\left(\mathrm{FEV}_{1}>\mathbf{8 0} \%\right.$ pred), all subjects had increased airway responsiveness to methacholine (provocation concentration producing a $20 \%$ fall in $\mathrm{FEV}_{1}=0.2-10.0 \mathrm{mg} \cdot \mathrm{ml}^{-1}$ ). BAL analysis showed similar median percentages of the total number of cells and differentials in control subjects and those exposed to HMW and LMW agents. Bronchial biopsies showed that mean inflammatory cell count, both epithelial and sub-epithelial, was similarily raised in OA subjects exposed to either HMW or LMW agents, compared to controls, except for epithelial lymphocyte count. In contrast to the controls, bronchial biopsy of both groups with $\mathrm{OA}$ also showed other changes such as extensive epithelial desquamation, ciliary abnormalities of the epithelial cells, smooth muscle hyperplasia and subepithelial fibrosis.

Bronchial biopsies from subjects with occupational asthma showed similar significant inflammatory changes after withdrawal from exposure to either high or low molecular weight sensitizing agent, even when symptoms were minimal. Eur Respir J., 1994, 7, 1567-1575.

\begin{abstract}
*Unité de Recherche, Centre de Pneumologie de l'Hôpital Laval, Université Laval, Québec, Canada. **The Dept of Chest Medicine, Hôpital du Sacré-Coeur Montréal, Canada.
\end{abstract}

Correspondence: L.P. Boulet

Hôpital Laval

2725 Chemin Sainte-Foy

Sainte-Foy (Québec)

Canada G1V 4G5

Keywords: Airway

asthma

bronchial biopsy

bronchial diseases

bronchoalveolar lavage fluid

occupational diseases

Received: June 41993

Accepted after revision March 251994

This work was funded by a UniversityIndustry grant from the Medical Research Council of Canada (Université Laval, Université de Montréal and Glaxo Canada). JLM is a senior researcher with the Université de Montréal School of Medicine and the Fonds de la recherche en santé du Québec.
In recent years, numerous studies have demonstrated that inflammation is a key feature of asthma [1-5]. Bronchoalveolar lavage (BAL) has shown that asthmatic subjects have more eosinophils, mastocytes and neutrophils than normal subjects $[6,7]$. Bronchial biopsies have also shown extensive damage of the epithelium and inflammatory reaction in the airways, even in those with mild asthma symptoms [8-11].

Occupational asthma (OA) is the most common occupational respiratory ailment $[12,13]$. Once subjects are removed from the workplace, the majority of subjects will still demonstrate significant airway hyperresponsiveness [14-18]. Studies on OA have shown that there is an influx of neutrophils or eosinophils in the BAL fluid after challenges with toluene diisocyanate (TDI) or plicatic acid that causes late asthmatic reactions $[19,20]$.
Bronchial biopsies in subjects with OA due to TDI showed an increased number of inflammatory cells, such as eosinophils, in the airway mucosa [21]. On electron microscopy, eosinophils and mast cells appeared degranulated. Intercellular spaces between epithelial cells were widened. There was a thicker subepithelial reticular layer, with deposition of Type III collagen. Six subjects were removed from exposure to TDI; there was reversal of the reticular basement membrane thickening but the inflammatory cell infiltrate persisted [22].

The physiopathology of OA due to low molecular weight (LMW) agents may be different from that which occurs after exposure to high molecular weight (HMW) agents. The mechanism of asthma caused by LMW agents remains unknown for most agents, whereas an immunoglobulin E ( $\operatorname{IgE})$-mediated phenomenon has been 
clearly identified for HMW agents, generally proteinderived antigens. Moreover, BAL and biopsy assessments have been performed in only six subjects after removal from exposure, all to TDI [22]. This study was designed: 1) to evaluate the presence and characteristics of airway inflammation in a larger group of workers with confirmed OA after a wider interval of removal from exposure; and 2) to compare the features of inflammation induced by either HMW or LMW agents.

\section{Methods}

\section{Subjects}

Eighteen subjects (11 men and 7 women) aged 20-54 yrs (mean 33 yrs), who had been referred to the Laval and Sacré-Coeur hospitals for investigation of OA, were enrolled in the study. Twelve were atopic (see below), three were smokers (1, 9 and 16 pack-years), two were ex-smokers (8 and 9 packs-years). All had recently had the diagnosis of OA to HMW (total=11; flour=7; psyllium, lobster, shrimp and tobacco $=1$ each) or LMW (total $=7$; hexamethylene diisocyanate $(\mathrm{HDI})=4$; welding=2; zinc $=1$ ) agents confirmed. The mean duration of exposure at work was 113 months (range 7-432 months), and the mean duration of symptoms while at work was 33 months (range 2-108 months). The criteria for inclusion were: 1) the diagnosis of $\mathrm{OA}$ was confirmed by specific inhalation challenges in all instances, except one in which monitoring of peak expiratory flow rate was used; 2) the subjects' exposure to the offending agent had ended (mean interval of 10 weeks; range 3-24 weeks; $\leq 16$ weeks in 16 out of 18 subjects); 3 ) subjects had not required inhaled or oral steroids since leaving work; 4) no other clinically relevant perennial allergen (except for house dust) was present in their usual environment; 5) the provocative concentration of methacholine causing a $20 \%$ fall in forced expiratory volume in one second $\left(\mathrm{PC}_{20} \mathrm{FEV}_{1}\right)$ was $\leq 16 \mathrm{mg} \cdot \mathrm{ml}^{-1}$ (significant bronchial hyperresponsiveness); 6) bronchoscopy was carried out 3-24 weeks from the time of diagnosis (therefore, after specific inhalation challenges in 17 out of 18 instances); and 7) subjects had not used inhaled or oral steroids in the 3 months preceding entry into the study. One subject had taken inhaled beclomethasone for four months at a low dose (400 $\mu$ g daily), whilst eight others had had short courses (less than one month) of inhaled steroids at a time when they were still exposed but still 3 months or more before enrolment.

Results were compared with data obtained from 10 normal controls, not exposed to agents causing OA. They included 8 men and 2 women, aged 20-32 yrs (mean $24 \mathrm{yrs}$ ). The normal subjects had no past history of

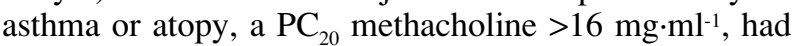
never smoked and were on no medication. They had no evidence of recent upper or lower airway infection.

All the asthmatic subjects used an inhaled beta -ago- $^{-}$ nist agent if needed (not daily). In the month preceding their entry to the study, none of the asthmatic subjects had had a respiratory infection or an increase in asthma symptoms. The study conformed with the Helsinki dec- laration and was approved by the Ethics Committees of Laval and Sacré-Coeur Hospitals. The subjects had given written consent.

\section{Assessment}

Spirometry and responsiveness to inhaled methacholine were measured according to a standardized procedure, using a Wright's nebulizer at tidal volume breathing for 2 min (output $=0.14 \mathrm{ml} \cdot \mathrm{min}^{-1}$ ), two weeks before undergoing bronchoscopy [23]. Skin prick tests with a battery of 15 common inhalants had been carried out before entry into the study. Atopy was present if one or more positive $(>3$ $\mathrm{mm}$ wheal) tests to the inhalants, a reaction to histamine phosphate at $1 \mathrm{mg} \cdot \mathrm{ml}^{-1}$ and a negative reaction to the diluent were seen. BAL analysis was performed in blind fashion by a designated technician at each centre, and biopsies were examined, also in a blind fashion, by the same pathologist for the two centres (MB, Hôpital Laval).

\section{Bronchoscopy lavage and biopsies}

Before the bronchoscopy, a $200 \mu \mathrm{g}$ dose of salbutamol was given using a metered-dose inhaler. All subjects received oxygen at $5 \mathrm{l} \cdot \mathrm{min}^{-1}$ via a nasal catheter during bronchoscopy. Vital signs, electrocardiograph and oximetry were recorded throughout the procedure. Spirometry was performed before and after the procedure, and patients were kept under observation for at least one hour after the bronchoscopy. Spirometry and bronchoalveolar lavages were performed according to standard guidelines [24, 25]. After local anaesthesia of the throat, larynx and bronchi with 2 and $4 \%$ lidocaine, the flexible bronchoscope (Olympus OES 10 fibrescope, Olympus, Markham, ONT, Canada) was introduced into the bronchial tree and gently wedged into a segmental or subsegmental bronchus of the right middle lobe. Four $50 \mathrm{ml}$ aliquots of normal saline $\left(37^{\circ} \mathrm{C}\right)$ were instilled and aspirated with a syringe or with mild suction via the bronchoscope channel. BAL fluids were kept on ice. After gauze filtration, the lavage fluid was pooled and the total number of cells was estimated on a haemocytometer. Cell differentials were obtained by counting at least 300 cells on glass cover preparations from the pooled lavage fluid and stained using Diff-Quik or nonspecific esterase stains as described previously [26]. The search for ciliated epithelial cells was performed by counting 1,000 cells on Diff-Quik stained preparations. The meta-chromatic cell count was carried out using toluidine blue stained preparations and counting at least 1,000 cells [26].

Bronchial biopsies were taken immediately after the lavages, on the same side. Six to eight specimens were taken from the carinae of the right upper and lower lobes and the segmental bronchi of the upper and lower lobes using conventional forceps. For light microscopy, routine studies were carried out after biopsies were fixed in Bouin's solution. The following light microscopic staining techniques were performed on all sections: haematoxylin and eosin; Masson's trichrome, Giemsa; periodic acid-Schiff (PAS); PAS with diastase digestion; and Weigert. Inflammatory cells were classified as follows: 
lymphocytes, plasmocytes, monocytes, macrophages, mast cells, polymorphonuclears (neutrophils, eosinophils and basophils), and unidentified cells.

Measurements were obtained on bronchial specimens examined with a light microscope (Zeiss), using an image analysis system (Mocha, Jandel Scientific, San Rafael, USA). The measurements included the degree of subepithelial fibrosis (mean of three measurements from histological sections stained with Massons' trichrome), percentage of epithelial desquamation, biopsy surface in $\mathrm{mm}^{2}$, and inflammatory cell type per $\mathrm{mm}^{2}$. The percentage of cell desquamation was measured by evaluating the length of the basement membrane denuded of epithelial cells over the total length of the basement membrane. Biopsy surface was evaluated for cell count, as the surface of connective tissue excluding smooth muscle cells and mucous glands.

Samples for electron microscopic studies were fixed by immersion in Karnovsky's fluid, washed in cacodylate buffer, osmicated, dehydrated in alcohol and embedded in Epon. Half of the samples were treated "en bloc" with uranyl acetate. Sections were stained with lead citrate and analysed using a Jeol 100 CX electron microscope. Electron microscopic studies evaluated cellular alterations, cilial abnormalities, evidence of cell activation (degranulation) and basement membrane changes, and subepithelial fibrosis. The mean number of cilia per epithelial cell was evaluated in each group from available electron micrographs.

\section{Analysis of results}

Reference values for spirometry were taken from KNUDSON et al. [27]. A $\mathrm{PC}_{20} \leq 16 \mathrm{mg} \cdot \mathrm{ml}^{-1}$ was considered indicative of increased bronchial responsiveness [28].

BAL cell differentials were compared using parametric analysis as normality and homogeneity of variance assumptions were met. Results were considered to be statistically significant if the p-value was $\leq 0.05$ with a multivariate test. For each of the five BAL parameters, as well as for the total number of cells and the percentage of lymphocytes, macrophages, neutrophils and eosinophils, the Bonferroni's inequality was applied; the results were, therefore, considered significant if the $p$ values were $\leq 0.05 / 5=0.01$, to obtain an overall 0.05 level of significance. To compare pairs of group means, we used the Tukey's multiple comparison procedure at 0.01 for each parameter. Original data from the bronchial biopsy analysis were transformed. For each bronchial biopsy parameter, the number of lymphocytes, macrophages, neutrophils, eosinophils and metachromatic cells $\cdot \mathrm{mm}^{-2}$ surface, we replaced the original observations, $\mathrm{X}$ values, to a different form, $\mathrm{X}^{\prime}=\mathrm{X}^{(1-\mathrm{C})}$, where $\mathrm{c}$ is a constant of proportionality obtained from the regression of log (variance) on $\log$ (mean). The values calculated for each parameter have made it possible to obtain a variance stabilizing transformation. For each of these last parameters, the results were considered to be significant if the $p$-value was $\leq 0.0083$, to obtain a overall 0.05 level of significance. For subepithelial fibrosis and percentage of epithelial desquamation, we replaced the observations by their ranks as no variance stabilizing transformation was encountered, with a 0.05 level of significance. Lymphocyte and eosinophil counts of epithelium were analysed using the same method (rank transformation).

Fisher exact probability test was also used for comparison of clinical and functional indices of subjects in the HMW and LMW groups.

\section{Results}

\section{Clinical and functional findings}

There were no significant differences in the baseline clinical and functional parameters between the HMW and LMW groups of subjects, except that subjects with LMW-induced asthma had a shorter interval since the end of exposure at work ( 6 and 13 months, respectively; $\mathrm{p}=0.02)$. Eight subjects $(73 \%)$ with HMW asthma and 4 (57\%) with LMW asthma were also sensitized to at least one other common airborne allergen. However, they had no symptoms related to exposure to these antigens at the time of the study. All but three subjects (Nos 12, 14 and 15 ) had normal ( $\geq 80 \%$ predicted) forced expiratory volume in one second $\left(\mathrm{FEV}_{1}\right)$ (table 1$)$. Ten subjects $(9$ HMW and 1 LMW) had an isolated early asthmatic response (EAR: fall in $\mathrm{FEV}_{1}>20 \%$ within the first hour of the challenge) to the offending agent. Four others (3 HMW and $1 \mathrm{LMW}$ ) had isolated late responses (LAR: fall in $\mathrm{FEV}_{1}>15 \%$ between 2 and $8 \mathrm{~h}$ after the challenge). Three subjects (2 LMW and 1 HMW) had dual responses (table 1). More subjects in the HMW group had isolated immediate asthmatic reactions $(9 / 11,82 \%)$; whereas, more subjects in the LMW group had dual or isolated late asthmatic reactions $(5 / 6,82 \%)(\mathrm{p}<0.01)$.

\section{Bronchoalveolar lavages}

The median number of cells $\left(\times 10^{4} \cdot \mathrm{ml}^{-1}\right)$ from subjects with asthma induced by HMW agents (15.2) and LMW (26.6) agents were significantly higher $(\mathrm{p}=0.03)$ than the controls (9.3). The differentials (in \%) were similar for the three groups (HMW, LMW, controls): macrophages 77, 83 and 79; lymphocytes 18, 13 and 18; neutrophils 1,2 and 1; eosinophils 0,1 and 0.5 ; epithelial cells 0.7 , 0.8 and 0.9 ; mast cells $(\mathrm{n}=9) 0.1,0$ and 0 (all $\mathrm{p}>0.05$ ). Counts for mast cells were only obtained from one of the two centres (Laval), but for these nine subjects, they were not higher between subjects with HMW or LMW $\mathrm{OA}$ and the controls $(0.1,0$ and $0 ; \mathrm{p}=0.19)$.

\section{Bronchial biopsies}

Biopsy material was adequate for light and electron microscopy analysis and included the epithelium and the submucosa. Light microscopic examination of bronchial biopsies showed good quality specimens in the three experimental groups. In contrast with the controls, the bronchial biopsies of subjects with OA showed evidence of airway inflammation, with numerous inflammatory cells, epithelial desquamation and subepithelial fibrosis. In control subjects and those with asthma due to HMW 
Table 1. - Physiological parameters

\begin{tabular}{|c|c|c|c|c|c|c|c|c|}
\hline \multirow{3}{*}{ No. } & \multirow{2}{*}{\multicolumn{2}{|c|}{$\begin{array}{c}\text { Baseline } \\
\mathrm{FEV}_{1}\end{array}$}} & \multirow{2}{*}{\multicolumn{2}{|c|}{$\begin{array}{c}\text { Baseline } \\
\text { FVC }\end{array}$}} & \multirow{3}{*}{$\begin{array}{c}\text { Baseline } \\
\mathrm{FEV}_{1} / \mathrm{FVC} \\
\%\end{array}$} & \multirow{3}{*}{$\begin{array}{c}\mathrm{PC}_{20} \\
\text { methacholine } \\
\mathrm{mg} \cdot \mathrm{ml}^{-1}\end{array}$} & \multicolumn{2}{|c|}{ Specific challeng } \\
\hline & & & & & & & $\overline{\mathrm{EAR}}$ & LAR \\
\hline & & $\%$ pred & $l$ & $\%$ pred & & & \multicolumn{2}{|c|}{$\%$ fall in $\mathrm{FEV}_{1}$} \\
\hline \multicolumn{9}{|c|}{ Low molecular weight agents $(n=7)$} \\
\hline 1 & 4.04 & 94 & 4.67 & 94 & 87 & 1.10 & 15 & 25 \\
\hline 4 & 3.47 & 99 & 4.79 & 111 & 72 & 4.60 & 20 & 26 \\
\hline 5 & 3.86 & 100 & 5.20 & 109 & 74 & 2.94 & 0 & 47 \\
\hline 8 & 3.59 & 103 & 4.15 & 97 & 87 & 0.99 & ND & ND \\
\hline 10 & 2.54 & 103 & 3.32 & 111 & 77 & 2.80 & 0 & 20 \\
\hline 12 & 2.00 & 62 & 3.10 & 79 & 65 & 0.33 & 43 & 0 \\
\hline 14 & 2.27 & 73 & 3.80 & 100 & 60 & 0.58 & 0 & 28 \\
\hline Mean & 3.11 & 91 & 4.15 & 100 & 75 & 1.3 & - & - \\
\hline SEM & 0.31 & 6 & 0.30 & 5 & 4 & - & - & - \\
\hline
\end{tabular}

High molecular weight agents $(n=11)$

\begin{tabular}{|c|c|c|c|c|c|c|c|c|}
\hline 2 & 2.43 & 80 & 3.36 & 93 & 72 & 0.75 & 60 & 0 \\
\hline 3 & 3.32 & 86 & 4.73 & 99 & 70 & 0.75 & 35 & 0 \\
\hline 7 & 3.32 & 105 & 3.91 & 104 & 85 & 3.10 & 59 & 31 \\
\hline 11 & 4.22 & 101 & 5.20 & 104 & 81 & 1.52 & 32 & 0 \\
\hline 13 & 3.07 & 101 & 3.63 & 102 & 85 & 1.05 & 25 & 0 \\
\hline 17 & 3.36 & 97 & 4.69 & 112 & 72 & 1.39 & 22 & 0 \\
\hline 18 & 4.01 & 115 & 4.85 & 119 & 83 & 2.42 & 0 & 20 \\
\hline Mean & 3.42 & 100 & 4.39 & 106 & 78 & 1.1 & - & - \\
\hline SEM & 0.16 & 5 & 0.18 & 4 & 2 & - & - & - \\
\hline
\end{tabular}

$\mathrm{FEV}_{1}$ : forced expiratory volume in one second; FVC: forced vital capacity; $\mathrm{PC}_{20}$ : provocative concentration producing a $20 \%$ fall in $\mathrm{FEV}_{1}$; EAR: early asthmatic response; LAR: late asthmatic response; ND: not determined, diagnosis proved by serial monitoring of peak expiratory flow rates.

and LMW agents, mean "apparent" basement membrane thickness (basement membrane and subepithelial fibrosis) was, respectively, 6.7, 17.5, $18.3 \mu \mathrm{m}$. Squamous cell metaplasia was present in all patients with OA. Epithelial desquamation was observed in association with inflammatory changes, and, compared to controls, was increased in subjects with asthma due to HMW or LMW agents (\% desquamation: $32.5,55.7$ and 41.8 in the three groups; $\mathrm{p}=0.02$ ). Formation of cilia was decreased and the sub-epithelial reticular layer was thicker, compared to the controls $(\mathrm{p}<0.001)$. Smooth muscle cells, identified in specimen biopsies of 10 subjects with OA, were hypertrophic or hyperplastic. Mild fibrosis of the subepithelial connective tissue was observed on Masson's trichrome in eight subjects.

In subjects with asthma induced by HMW and LMW agents, we observed a statistically significant increase in the mean cell differentials (number of cells $\mathrm{mm}^{-2}$ of connective tissue) as follows (controls, HMW, LMW): lymphocytes $51.5,135.6$ and $162.3(\mathrm{p}=0.0008)$; monocytes and macrophages $1.5,12.1$ and $14.2(\mathrm{p}<0.001)$; neutrophils $2.5,15.0$ and $17.4(\mathrm{p}=0.005)$; eosinophils $0.6,22.3$ and $24.1(\mathrm{p}<0.001)$; mast cells $0,3.5$ and $6.8(\mathrm{p}<0.001)$; plasma cells $1.6,5.9$ and 9.2 ( $\mathrm{p}=0.04$ ) (fig. 1a). Inflammatory cell counts for the epithelium were (median of cells $\cdot \mathrm{mm}^{-2}$ surface) for controls and subjects exposed to HMW and LMW agents and controls were: eosinophils
0, 100.0 and $32.1 \quad(\mathrm{p}<0.001)$; and lymphocytes 125.0, 166.7 and 95.8 (NS) (fig 1b).

There was no difference in the median cell count of bronchial biopsies according to the type of causal agent, $\mathrm{PC}_{20}$, baseline $\mathrm{FEV}_{1}$, duration of asthma, time since last exposure or duration of exposure (NS). We also reanalysed results of BAL and biopsies by excluding all those $(n=5)$ who had a smoking history, whatever the number of years. The analysis still showed significant differences by comparison with the control group in subepithelial fibrosis $(\mathrm{p}=0.001)$ and for the number $\left(/ \mathrm{mm}^{2}\right.$ of connective tissue) of lymphocytes ( $\mathrm{p}<0.001)$, eosinophils $(\mathrm{p}<0.001)$, monocytes-macrophages $(p<0.001)$, neutrophils $(p<0.001)$, mast cells $(p<0.001)$ and plasma cells $(p=0.08)$ in the biopsies. Among subjects with asthma induced by HMW agents and LMW agents as compared to controls, we observed a statistically significant increase in eosinophils $(\mathrm{p}<0.001)$ in the epithelium (median of cells $/ \mathrm{mm}^{2}$ surface) but not in lymphocytes $(\mathrm{p}=0.53)$. Granulated mast cells were absent. There were no significant differences in features of BAL.

On electron microscopy, in asthma induced by either HMW or LMW agents, epithelial cells (fig. 2) showed intercellular oedema and partial separation of junctional complexes, mitochondrial swelling, dilatation of smooth endoplasmic reticulum, and loss of glycogen. Some cells were devoid of cilia or showed cilial alterations, such as 

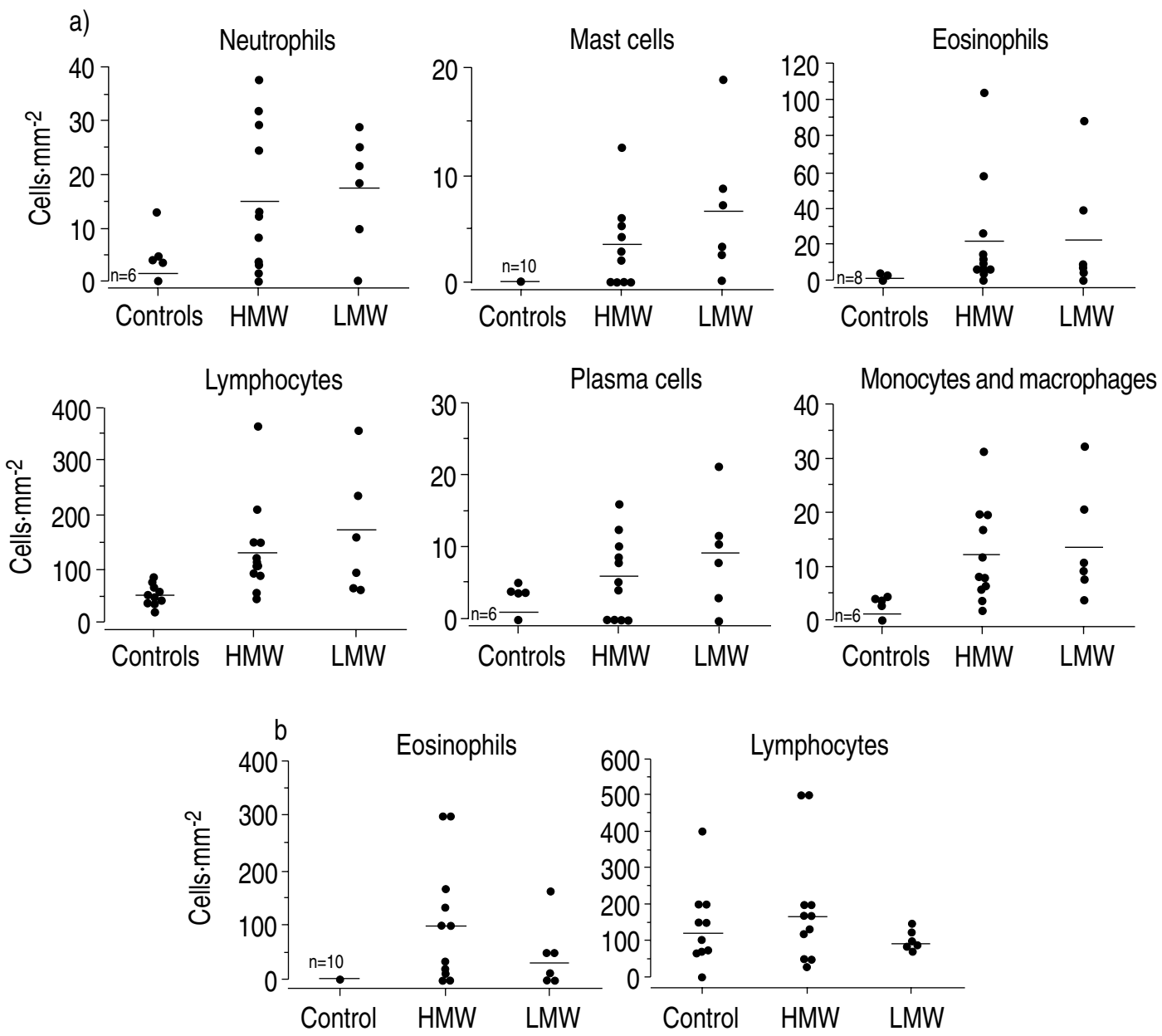

Fig. 1. - a) Comparison of cell differentials of bronchial biopsies from control subjects and those with asthma induced by high (HMW) or low (LMW) molecular weight agents in the subepithelial area (cells $\cdot \mathrm{mm}^{-2}$ connective tissue). There was a significant increase in all inflammatory cell counts, with the exception of plasma cells, in subjects with occupational asthma compared to controls. Mean values are shown by the horizontal lines. $\mathrm{n}$ values indicate the number of points at the specific place. For each of these last parameters, the results were considered to be significant if the $\mathrm{p}$ value was $\leq 0.0083$ to obtain and overall 0.05 level of significance. b) Comparison of cell differentials of bronchial biopsies from control subjects and those with asthma induced by HMW or LMW agents in the epithelium (median cells $\cdot \mathrm{mm}^{-2} \mathrm{surface}$ ).

incomplete formation of cilia from basal corpuscles, blebs formation and separation from the apical portion of the cell membrane containing numerous cilia. Ciliated cells showed a mean number of 9.0 cilia per cell in controls and 1.9 in asthmatics $(\mathrm{p}<0.01)$. Impaired genesis of cilia was associated with the accumulation in the cytoplasm of apical cells of contractile filaments associated with basal corpuscle formation (fig. 3a and b). In areas of epithelial desquamation, a persistence of basal cells attached to the basement membrane by hemidesmosomes was noted. Focal areas of squamous cell metaplasia were characterized by ovoid cells with larger and longer desmosomes, to which were attached tonofilaments (fig. 3c). The true basement membrane (nonreticular) was not thickened, but there were numerous reticulo-collagenic fibres beneath the epithelial layer (increased reticular basement membrane). Connective tissue cells showed fibroblasts with contractile filaments (myofibroblasts). In the subepithelial connective tissue, various inflammatory cell types were observed, such as lymphocytes, mast cells, polymorphonuclear cells (eosinophils and neutrophils). Some of these cells were partially degranulated (fig. 4 a-d).

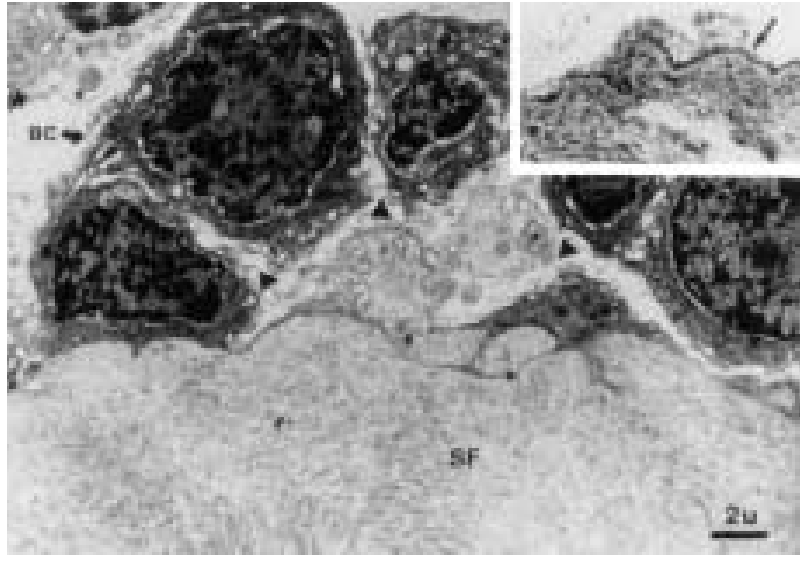

Fig. 2. - Subject with occupational asthma. Right upper insertion: epithelial desquamation (arrow) with remaining epithelial basal cells overlying subepithelial fibrosis (thickened subepithelial reticular layer). Main panel: electron micrograph of the area illustrated by the arrow, showing the reticulo-collagenic subepithelial fibrosis (SF) covered by a single layer of basal cells (BC) devoid of cilia. On the top, note intercellular separation of basal cells (arrowheads). (Original magnification $\times 7,200$; bar $=2 \mu \mathrm{m}$ ). 

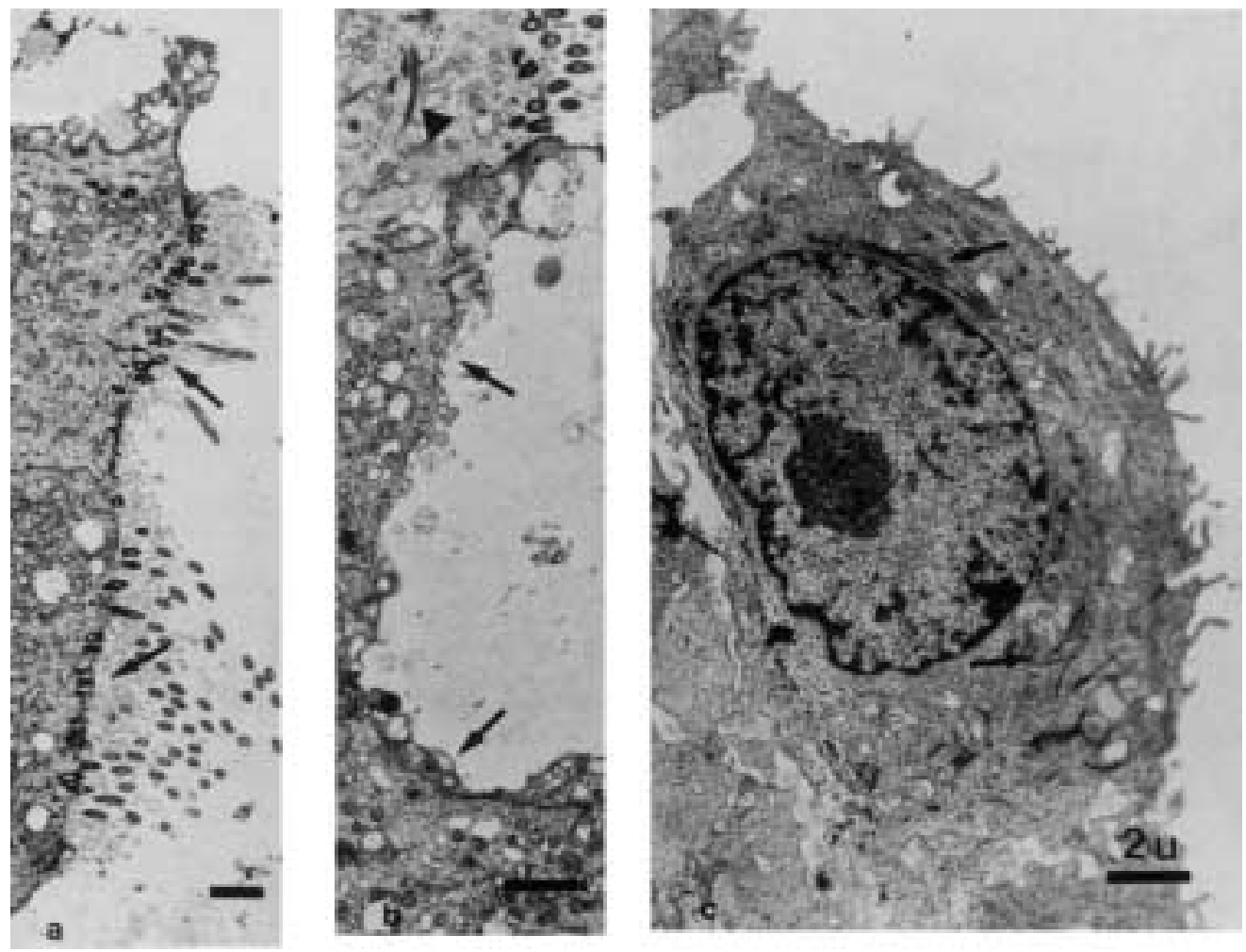

Fig. 3. - Electron micrograph of epithelial and inflammatory cells in occupational asthma (bars=2 um). a) Incomplete genesis of cilia (arrows), with few cilia and basal corpuscles. (Original magnification $\times 4,800$ ); b) Two cells are completely devoid of cilia (arrows). Arrow-head shows incomplete basal corpuscle formation with accumulation of ciliary rootless material in apical portion of a cell with few cilia. (Original magnification $\times 6,700$ ); c) Squamous cell metaplasia with desmosomes and cytoplasmic filaments (arrows). (Original magnification $\times 6,700$ ).
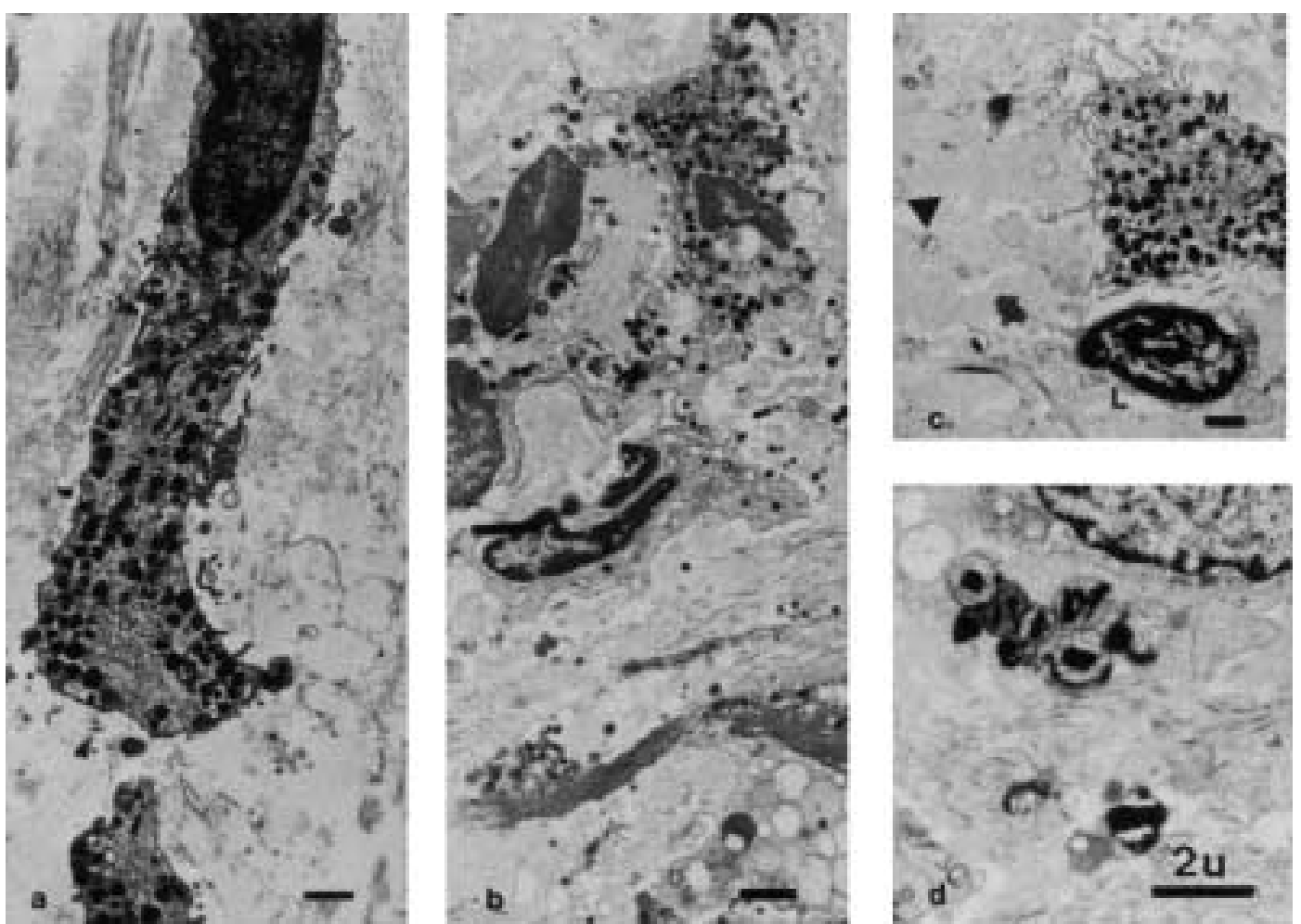

Fig. 4. - Electron micrograph of inflammatory cells in occupational asthma (bars=2 $\mu \mathrm{m}$ ). a) Mast cell in the process of releasing secretory granules into connective tissue. (Original magnification $\times 4,800$ ). b) Polymorphonuclears releasing numerous granules into connective tissue. (Original magnification $\times 5,400$ ); c) Lymphocyte (L) and mast cell (M) partially degranulated. Note empty eosinophilic granules (arrow-head). (Original magnification $\times 3,800$ ). d) High magnification of free eosinophilic granules with crystalloid central part. (Original magnification $\times 9,400$ ). 


\section{Discussion}

In this study, carried out in subjects with OA 3-24 weeks after removal from exposure, we showed: 1) marked inflammatory changes in the bronchial biopsy of subjects with OA, such as an increased numbers of inflammatory cells, extensive epithelial desquamation, ciliary loss and abnormalities, subepithelial fibrosis (thickened subepithelial reticular layer) and smooth muscle hyperplasia; and 2) no significant difference in the type and extent of airway inflammation according to whether the asthma was induced by HMW or LMW agents and regardless of the duration of asthma symptoms.

Previous studies on the inflammatory changes in OA after removal from exposure were performed in six subjects exposed to toluene diisocyanate (TDI) [22, 29]. Our results extend these findings to a larger group of subjects and to HMW agents, which cause sensitization through an IgE-dependent mechanism, similar to "extrinsic asthma". Even if several HMW agents were incriminated, the mechanism was IgE-dependent in all instances, as confirmed by a positive immediate skin reaction to the causal agent. Therefore, the HMW group should not be considered as heterogeneous, even if there were several causal agents

Our findings are in keeping with those described in atopic or nonatopic non-OA, showing alterations of the bronchial epithelium and ciliary structure, and an increase in airway inflammatory cells, such as eosinophils, neutrophils and activated lymphocytes [8-11, 30-32]. We observed similar findings in our subjects with OA, as well as shedding of the epithelium, collagen deposition beneath the epithelial basement membrane, partial mast cell degranulation and eosinophil infiltration of the lamina propria.

Our observations are also in keeping with another report on asthma induced by a LMW agent (TDI), showing the presence of airway inflammation, widening of the intercellular spaces between columnar cells, thickening of the subepithelial reticular layer, with deposition of Type III collagen, and evidence of degranulation of eosinophils and mast cells [22]. The observation of a common inflammatory pattern in OA induced both by HMW and LMW is also in keeping with the findings of BENTLEY et al. [31], who looked at the state of activation of lymphocytes in isocyanate-induced asthma. Five subjects with TDI-induced asthma and four with methylene diisocyanate-induced asthma had bronchial biopsies taken, which were compared to 12 allergic asthmatics and 12 normal subjects. There was a significant increase in CD25+ cells (interleukin-2 receptor bearing cells) and in major basic protein positive and EG2+ cells seen in isocyanate-induced asthma and in extrinsic allergic asthmatics. There was, however, no difference in the number of T-lymphocyte phenotypic markers (CD3, CD4, CD8) between asthmatics and controls. The ciliary abnormalities observed in OA were also found in one of our previous studies on allergic asthma [30]. These alterations may play a role in regeneration of cilia and may increase the contractile potential of cells influencing the epithelial desquamation process. The accumulation of contractile material in epithelial cells may indicate abnormal basal corpuscle formation and a reduced number of cilia at the epithelial cell surface.

Regarding the cell counts, we should point out that it is difficult to compare our observations on mast cells, made on light microscopy, with other techniques such as electron microscopy, as it may be difficult to identify degranulated cells with the first method. PESCI et al. [33] have shown the heterogeneity of mast cells in the bronchial muscosa, and have reported the absence of granulated mast cells in the airway epithelium in asthma, whilst they represented about one third of the total cell count in the lamina propria. Furthermore, we had an increased number of neutrophils in bronchial biopsies of subjects with occupational asthma, compared to previous studies reporting bronchial biopsy analysis in asthma. These neutrophils were clearly identified on electron micrographs, as shown in figure $4 \mathrm{~b}$. It is possible that subjects with occupational asthma have different cell changes compared to the other types of asthma. Furthermore, up to the present time in the literature, many asthmatic subjects biopsied had recently diagnosed asthma, whilst ours sometimes had evidence of asthma for prolonged periods of time, up to 108 months (mean 33 months), before withdrawal from the workplace.

We found no significant increase in metachromatic and epithelial cells through BAL analysis, as has been previously described in allergic asthma. Our results are, however, in keeping with those of researchers looking at BAL in TDI-induced [19] and Western red cedarinduced [20] asthma, showing minimal changes before late asthmatic responses, although the late response was associated with an influx of neutrophils or eosinophils in the BAL fluid. Baseline airway inflammation in subjects with OA after removal from exposure is, therefore, more evident in bronchial biopsies than in BAL fluid. Biopsies represent a more direct means of investigating the pathophysiology of asthma than does BAL [34]. BAL findings can show minimal changes in terms of markers of inflammation, whilst marked inflammatory changes may be found in the airway wall $[8,30]$. Moreover, we do not think that the failure to find significant changes in BAL is due to the relative insensitivity of our method. This methodology is accurate, has been standardized, has been found comparable to the other methods [26], and is capable of picking up differences in BAL cells in many disorders [35-37]. This comment also applies for biopsy studies that were performed according to recently published methodologies [10]. Sampling of bronchial tissue may cause artifactual damage but, if this is the case, it should be identical in normal controls and in subjects exposed to either HMW or LMW agents. Our sampling methodology allowed us to obtain airway smooth muscle, and smooth muscle hyperplasia is evident on light microscopy, where the number of muscular cells is increased. We could also assess subepithelial fibrosis using a standard morphological method. We therefore think that biopsies may be more appropriate for looking at airway inflammation in stable asthmatics, whilst BAL may be more useful after bronchial provocation, where increases in cell influx have been documented. 
Although the number of studies on airway inflammation is limited, our study and others [21,31] suggest that inflammatory features are similar, regardless of whether the inducing agent is occupational or a common airborne antigen. Differences may be minimal, and perhaps only detected by immunohistochemical studies which more specifically address the functional state of cells. However, the purpose of this study was not to assess the functional state of various cell populations but, rather, to describe the inflammatory process in a more general manner, by identifying various histopathological features. The functional state will have to be explored further in future studies.

The fact that the interval since removal from exposure varied from 3-24 weeks (although it was $\leq 16$ weeks in 16 out of 18 subjects) did not seem to affect our results. Biopsy material all showed features of inflammation, and there was no relationship between the extent of inflammation and the interval since removal from exposure. Our results extend to a wider interval, those of SAETTA and co-workers [22], studying six subjects who had not been exposed for a fixed interval of 6 months ( 24 weeks).

It can be argued that the fact that most of our subjects were atopic could explain why they were left with permanent inflammatory sequelae and persisting asthma. This possibility is unlikely, for the following reasons. Atopy is a frequent finding in a general population. In previous studies, we showed that the prevalence of atopy, defined by at least one immediate skin reaction to a battery of common inhalants, was $60-76 \%$ [38-40]. However, only $2-5 \%$ of these had OA. In this study, 12 out of 18 subjects $(67 \%)$ were atopic, which corresponds to proportions found in our previous population studies. It seems unlikely that atopy defined by skin testing (this was the case in subjects with OA), or in controls (as defined by history), can affect results of biopsies, as atopy is a genetic marker and should not alter the histopathological features if no target organ, such as the bronchi in asthma, is involved. Activation of inflammatory cells was demonstrated in 10 atopic subjects described by BRADLEY et al. [41], but six of these had evidence of rhinoconjunctivitis. These results should, therefore, not be interpreted as showing that atopy per se can influence airway inflammation. In keeping with the persistence of airway inflammation after cessation of exposure to a sensitizing substance at work, PAGGIARo et al. [29] also showed that after cessation from exposure to TDI, persistence of airway hyperresponsiveness in sensitized subjects was associated with an increased number of eosinophils in BAL fluid.

Finally, the diagnosis of OA was always based on the following: 1) no subject had a history of asthma before starting exposure to the causal agent; 2) no subject had respiratory symptoms on exposure to common airborne allergens; 3) the history was always that subjects were more symptomatic during a working period than when they were away from work; and 4) specific inhalation challenges to the causal agent proved the relationship between exposure and symptoms. Therefore, even though we cannot entirely exclude the possibility that the persisting asthma was due to other causes, the clinical and functional evidence points out that the occupational agent was at least the principal cause of the asthma. In the same way, we do not think that smoking affected our results. Indeed, by excluding smokers or ex-smokers of $>10$ packs-years $(n=5)$ from the analysis, we showed that smoking did not alter our results.

In conclusion, this study shows that in subjects with OA who had been recently removed from exposure, no significant increase in inflammatory cells could be found in BAL fluid but bronchial biopsies show significant airway inflammatory changes using both light and electron microscopy, which were not different in subjects with asthma induced by high and low molecular weight agents.

Acknowledgements: The authors would like to thank K. Tallman for reviewing this manuscript.

\section{References}

1. Chung KF. Role of inflammation in the hyperreactivity of the airways in asthma. Thorax 1986; 41: 657662.

2. Kay AB. In: Allergy and Inflammation. London, Academic Press, 1987.

3. O'Byrne PM. Airway inflammation and airway hyperresponsiveness. Chest 1986; 90: 575-577.

4. Kay AB. Asthma and inflammation. J Allergy Clin Immunol 1991: 87: 893-910.

5. Bousquet J, Chanez P, Lacoste JY, et al. Eosinophilic inflammation in asthma. N Engl J Med 1990; 323: 1033-1039.

6. Kirby JG, Hargreave FE, Gleich GJ, O'Byrne PM. Bronchoalveolar cell profiles of asthmatic and nonasthmatic subjects. Am Rev Respir Dis 1987; 136: 379-383.

7. Wardlaw AJ, Dunnette S, Gleich GJ, Collins JV, Kay AB. Eosinophils and mast cells in bronchoalveolar lavage in subjects with mild asthma. Am Rev Respir Dis 1988; 137: 62-69.

8. Djukanovic R, Roche WR, Wilson, et al. Mucosal inflammation in asthma. Am Rev Respir Dis 1990; 142: 434-457.

9. Roche WR, Beasley R, Williams JH, Holgate ST. Subepithelial fibrosis in the bronchi of asthmatics. Lancet 1989; i: 520-524.

10. Jeffery PK, Wardlaw AJ, Nelson FC, Collins JV, Kay AB. Bronchial biopsies in asthma. An ultrastructural, quantitative study and correlation with hyperreactivity. Am Rev Respir Dis 1989; 140: 1745-1753.

11. Azzawi M, Bradley B, Jeffery PK, et al. Identification of activated T-lymphocytes and eosinophils in bronchial biopsies in stable atopic asthma. Am Rev Respir Dis 1990; 142: 1407-1413.

12. Lagier F, Cartier A, Malo JL. Medico-legal statistics on occupational asthma in Quebec between 1986 and 1988. Rev Mal Respir 1990; 7: 337-341.

13. Meredith SK, Taylor VM, McDonald JC. Occupational respiratory disease in the United Kingdom 1989: a report to the British Thoracic Society and the Society of Occupational Medicine by the SWORD project group. Br J Ind Med 1991; 48: 292-298.

14. Chan-Yeung M, Lam S, Koener S. Clinical features and natural history of occupational asthma due to western red cedar (Thuja plicata). Am J Med 1982; 72: 411-415. 
15. Burge PS. Occupational asthma in electronics workers caused by colophony fumes: follow-up of affected workers. Thorax 1982; 37: 348-353.

16. Mapp CE, Corona PC, De Marzo N, Fabbri L. Persistent asthma due to isocyanates. A follow-up study of subjects with occupational asthma due to toluene diisocyanate. Am Rev Respir Dis 1988; 137: 1326-1329.

17. Allard C, Cartier A, Ghezzo H, Malo JL. Absence of clinical and functional improvement in subjects with occupational asthma due to various agents at an interval of 4 or more years after cessation of exposure. Chest 1989; 96; 1046-1049.

18. Malo JL, Cartier A, Ghezzo H, Lafrance M, McCants M, Lehrer SB. Patterns of improvement in spirometry, bronchial hyperresponsiveness, and specific IgE antibody levels after cessation of exposure in occupational asthma caused by snow-crab processing. Am Rev Respir Dis 1988; 138: 807-812.

19. Fabbri LM, Boschetto P, Zocca E, et al. Bronchoalveolar neutrophilia during late asthmatic reactions induced by toluene diisocyanate. Am Rev Respir Dis 1987; 136: 36-42.

20. Lam S, LeRiche J, Phillips D, Chan-Yeung M. Cellular and protein changes in bronchial lavage fluid after late asthmatic reaction in patients with red cedar asthma. $J$ Allergy Clin Immunol 1987; 80: 44-50.

21. Saetta M, Di Stefano A, Maestrelli P, et al. Airway mucosal inflammation in occupational asthma induced by toluene diisocyanate. Am Rev Respir Dis 1992; 145: 160-168.

22. Saetta M, Maestrelli P, Di Stefano A, et al. Effect of cessation of exposure to toluene diisocyanate (TDI) on bronchial mucosa of subjects with TDI-induced asthma. Am Rev Respir Dis 1992; 145: 169-174.

23. Cockcroft DW, Killian DN, Mellon JJA, Hargreave FE. Bronchial reactivity to inhaled histamine: a method and clinical survey. Clin Allergy 1977; 7: 235-243.

24. American Thoracic Society Statement. Snowbird Workshop on Standardization of spirometry. Am Rev Respir Dis 1979; 119: 831-838

25. American Thoracic Society. Clinical role of bronchoalveolar lavage in adults with pulmonary disease. Am Rev Respir Dis 1990; 142: 481-486.

26. Laviolette M, Carreau M, Coulombe R. Bronchoalveolar lavage cell differential microscope glass cover. Am Rev Respir Dis 1988; 138: 451-457.

27. Knudson RJ, Lebowitz MD, Holberg CJ, Burrows B. Changes in the normal maximal expiratory flow-volume curve with growth and ageing. Am Rev Respir Dis 1983; 127: 725-734.

28. Malo JL, Pineau L, Cartier A, Martin RR. Reference values of the provocative concentrations of methacholine that cause $6 \%$ and $20 \%$ changes in forced expiratory volume in one second in a normal population. Am Rev Respir Dis 1983; 128: 8-11.
29. Paggiaro P, Bacci E, Paoletti P, et al. Bronchoalveolar lavage and morphology of the airways after cessation of exposure in asthmatic subjects sensitized to toluene diisocyanate. Chest 1990; 98: 536-542.

30. Boulet LP, Turcotte H, Boutet M, Laviolette M. Influence of antigenic exposure on expiratory flows, airway responsiveness and airway inflammation in mild seasonal asthma. J Allergy Clin Immunol 1993; 91: 883-893.

31. Bentley AM, Maestrelli P, Saetta M, et al. Activated T-lymphocytes and eosinophils in the bronchial mucosa in isocyanate-induced asthma. J Allergy Clin Immunol 1992; 89: 821-829.

32. Ollerenshaw SL, Woolcock AJ. Characteristics of the inflammation in biopsies from large airways in subjects with asthma and subjects with chronic airflow limitation. Am Rev Respir Dis 1992; 145: 922-927.

33. Pesci A, Foresi A, Bertorelli G, Chetta A, Olivieri D. Histochemical characteristics and degranulation of mast cells in the epithelium and lamina propria of bronchial biopsies from asthmatic and normal subjects. Am Rev Respir Dis 1993; 147: 684-689.

34. Monteforte S, Herbert CA, Robinson C, Holgate ST. The bronchial epithelium as a target for inflammatory attack in asthma. Clin Exp Allergy 1992; 22: 511-520.

35. Cormier Y, Bélanger J, Leblanc P, Laviolette M. Bronchoalveolar lavage in farmer's lung disease: diagnosis and clinical significance. Br J Ind Med 1986; 43: 401-405.

36. Laviolette M, Cormier Y, Loiseau A, Soler P, Leblanc M, Hance AJ. Bronchoalveolar mast cells in normal farmers and subjects with farmer's lung. Am Rev Respir Dis 1991; 144: 855-860.

37. Laviolette M, Laforge J, Tennina S, Boulet LP. Prognostic value of bronchoalveolar lavage lymphocyte count in recently diagnosed pulmonary sarcoidosis. Chest 1991; 100: 380-384.

38. Bardy JD, Malo JL, Séguin P, et al. Occupational asthma and $\operatorname{IgE}$ sensitization in a pharmaceutical company processing psyllium. Am Rev Respir Dis 1987; 135: 1033-1038.

39. Malo JL, Cartier A, L'Archevêque J, et al. Prevalence of occupational asthma and immunological sensitization to psyllium among health personnel in chronic care hospitals. Am Rev Respir Dis 1990; 142: 1359-1366.

40. Malo JL, Cartier A, L'Archevêque J, et al. Prevalence of occupational asthma and immunological sensitization to guar gum among employees at a carpet manufacturing plant. J Allergy Clin Immunol 1990; 86: 562-569.

41. Bradley BL, Azzawi M, Jacobson M, et al. Eosinophils, T-lymphocytes, mast cells, neutrophils, and macrophages in bronchial biopsy specimens from atopic subjects with asthma: comparison with biopsy specimens from atopic subjects without asthma and normal control subjects and relationship to bronchial hyperresponsiveness. J Allergy Clin Immunol 1991; 88: 661-674. 